\title{
Parathyroid hormone(1-34) and parathyroid hormone-related protein(1-34) stimulate calcium release from human syncytiotrophoblast basal membranes via a common receptor
}

\author{
W Farrugia ${ }^{1,2}$, T de Gooyer ${ }^{1}$, G E Rice ${ }^{2}$, J M Moseley ${ }^{3}$ \\ and M E Wlodek ${ }^{1,2}$ \\ ${ }^{1}$ Department of Physiology, University of Melbourne, Victoria 3010, Australia \\ ${ }^{2}$ Perinatal Research Centre, The Royal Women's Hospital, Carlton, Victoria 3053, Australia and Department of Obstetrics and Gynaecology, University of \\ Melbourne, Parkville, Victoria 3052, Australia \\ ${ }^{3}$ St Vincent's Institute of Medical Research, St Vincent's Hospital, Fitzroy, Victoria 3065 Australia \\ (Requests for offprints should be addressed to M E Wlodek, Department of Physiology, University of Melbourne, Victoria 3010, Australia; \\ Email: m.wlodek@physiology.unimelb.edu.au)
}

\begin{abstract}
The placental syncytiotrophoblast is the site for mineral and nutrient exchange across the maternal-fetal interface. It has been proposed that parathyroid hormone-related protein (PTHrP) is a key factor in the maintenance of a maternal-fetal calcium gradient. Using simultaneously prepared microvillous (maternal facing) and basal (fetal facing) syncytiotrophoblast membranes from term human placentae $(n=8)$, we determined the relative contribution of $\mathrm{PTH}(1-34), \mathrm{PTHrP}(1-34)$ and $\mathrm{PTHrP}(67-94)$ to the regulation of syncytiotrophoblast calcium efflux. The vesicles had correct right-side-out membrane orientation and specific markers validated the fractionation of microvillous and basal membrane vesicles. Calcium efflux was studied by preloading vesicles with calcium- 45 in the presence of calcium and magnesium and then incubating the vesicles at $37^{\circ} \mathrm{C}$ for $15 \mathrm{~min}$ with the peptides. In basal mem-
\end{abstract}

branes, PTHrP(1-34) significantly stimulated calcium efflux at a dose of $12.5 \mathrm{nmol} / 1$, whereas $\mathrm{PTH}(1-34)$ stimulated efflux was significant at $50 \mathrm{nmol} / 1 \quad(P<0 \cdot 05$, ANOVA). This efflux was significantly reduced in the presence of the $\mathrm{PTH} / \mathrm{PTHrP}$ receptor antagonist (PTHrP(7-34)). Midmolecule PTHrP(67-94) had no significant effect on basal membrane calcium efflux. PTH(134), PTHrP(1-34) or PTHrP(67-94) had no significant effects on MVM calcium efflux. This study, using the human syncytiotrophoblast in vitro membrane system, demonstrated that $\mathrm{PTHrP}(1-34)$ and $\mathrm{PTH}(1-34)$ stimulate calcium transport across the basal, but not microvillous, syncytiotrophoblast membrane vesicles, mediated via the $\mathrm{PTH} / \mathrm{PTHrP}$ receptor.

Journal of Endocrinology (2000) 166, 689-695

\section{Introduction}

Parathyroid hormone-related protein (PTHrP) is produced by many tissues, in which it is believed to have a number of physiological roles, particularly in the mother during pregnancy and in the developing fetus (Philbrick et al. 1996, Wysolmerski \& Stewart 1998). PTHrP, PTHrP mRNA and the common $\mathrm{PTH} / \mathrm{PTHrP}$ receptor have been identified in gestational tissues, including, myometrium, fetal membranes and placenta (Ferguson et al. 1992, Germain et al. 1992, Bowden et al. 1994, Curtis et al. 1997, 1998, Thiede et al. 1990), and in fetal tissues (Moniz et al. 1990, Moseley et al. 1991, Dunne et al. 1994). In the placenta, PTHrP and its mRNA have been identified in both syncytiotrophoblast and cytotrophoblast cells (Deftos et al. 1994, Dunne et al. 1994). Potential autocrine, paracrine and endocrine roles during pregnancy that have been proposed for PTHrP include regulation of cellular growth and differentiation (Alsat et al. 1993, Lee et al. 1995), vasodilatation of the uteroplacental vasculature (Mandsager et al. 1994, Macgill et al. 1997), relaxation of uterine muscle (Thiede et al. 1990, Williams et al. 1994, Dalle et al. 1992, Paspaliaris et al. 1992) and stimulation of placental calcium transport (Rodda et al. 1988, Care et al. 1990, Kovacs et al. 1996).

The placenta is responsible for the transfer of nutrients from the mother to the fetus. The fetus is normally hypercalcaemic with respect to its mother, and effective placental calcium transfer between the mother and the fetus requires an active transport process across the syncytiotrophoblast (Sideri et al. 1983). Although little is known regarding the regulation of human placental calcium transport, recent evidence from sheep suggests that PTHrP may be an important modulator of placental 
calcium transport. PTHrP derived from the fetal parathyroids is critical for the maintenance of the active placental calcium gradient, as demonstrated in thyroparathyroidectomy experiments in fetal lambs (Care et al. 1990, Rodda et al. 1988) and decapitation studies on fetal rats (Robinson et al. 1989). Using placental perfusion in the thyroparathyroidectomized fetal sheep, it has been shown that partially purified fetal parathyroid extracts, PTHrP(1-108), PTHrP(1-141) and PTHrP(67-86) amide, but not $\mathrm{PTH}(1-34)$, $\mathrm{PTH}(1-84)$ or $\mathrm{PTHrP}(1-34)$, increased placental calcium transport (Rodda et al. 1988, Care et al. 1990). In contrast, the findings of other sheep studies demonstrated an increase in placental calcium transport in response to $\mathrm{PTHrP}(1-34)$ and $\mathrm{PTH}(1-34)$ (Barlet et al. 1990). However, in these animals the presence of intact parathyroids, kidneys and skeleton complicate the interpretation of the data (Barlet et al. 1990). In another model in which fetal rats had been cervically dislocated to effect parathyroidectomy, $\mathrm{PTH}(1-$ 34) failed to have an effect on placental calcium transport (Robinson et al. 1989, Shaw et al. 1991). More recently, the work of Kovacs and colleagues (1996) has supported the notion that placental calcium transport is regulated by a midmolecule fragment of PTHrP. They showed that homozygous PTHrP gene knockout fetal mice of heterozygous mothers have reduced placental calcium transport (Kovacs et al. 1996, Tucci et al. 1996), which is increased by treatment with $\mathrm{PTHrP}(1-86)$ or $\mathrm{PTHrP}(67-86)$, but not PTHrP(1-34) or PTH peptides (Kovacs et al. 1996). Although PTH/PTHrP receptor gene knockout mice are hypocalcaemic, the observation that placental calcium transport was increased indicates that the $\mathrm{PTH} / \mathrm{PTHrP}$ receptor was not required for this function (Kovacs et al. 1996). Early evidence in the sheep model, including the identification of PTHrP within the placenta, suggested that, early in gestation, PTHrP derived from placenta is important in the maintenance of the maternal-fetal calcium gradient and this role may be taken over, at least in part, after further development of the fetal parathyroids later in gestation (Rodda et al. 1988, MacIsaac et al. 1991). It is possible that there are species differences in placental calcium regulation, but this remains to be established.

Transfer of calcium occurs across two structurally and functionally distinct regions of the placental syncytiotrophoblast's plasma membrane, the maternal-facing microvillous membrane (MVM) and a fetal-facing basal membrane (BM) (Sideri et al. 1983). Calcium is believed to enter the syncytiotrophoblast at the MVM passively down a concentration gradient. Entry of calcium occurs through channels or through calcium-binding proteins at the membrane surface. Calcium is moved across the cell by calcium-binding proteins that also act to buffer the changing intracellular concentrations and therefore assist in the maintenance of the concentration gradient. At the BM, calcium is extruded from the cell actively by a $\mathrm{Ca}^{2+}$-ATPase exchange mechanism (Fisher et al. 1987,
Borke et al. 1989). The active extrusion of calcium at the $\mathrm{BM}$ is suggested to be the rate-limiting step of placental calcium transport. An in vitro differential centrifugation and magnesium precipitation technique has been used in the isolation and purification of these two distinct membrane regions of the human syncytiotrophoblast (Smith et al. 1974, Kelley et al. 1983, Lafond et al. 1988, Illsley et al. 1990), and this technique provides a useful model with which to study placental calcium transport without the confounding effects of intact fetal parathyroids, skeletal or renal demands. This study aimed to investigate the role of PTHrP and the PTH/PTHrP receptor in the regulation of calcium transport across the human syncytiotrophoblast, using MVM and BM vesicles prepared by differential centrifugation and magnesium precipitation.

\section{Materials and Methods}

\section{Reagents}

All reagents were obtained from Sigma Chemical Co. (St Louis, MO, USA) unless otherwise stated.

\section{Tissue collection}

Human placentae were obtained (with Royal Women's Hospital, Research and Ethics Committee approval) at elective caesarean section before the onset of labour from uncomplicated pregnancies. Tissues were received in the laboratory within 10-15 min of delivery.

\section{Preparation of vesicles}

Vesicle preparation was according to the Illsley method, with a number of modifications (Illsley et al. 1990). All procedures were performed at $4{ }^{\circ} \mathrm{C}$ unless otherwise stated. Duplicate $40 \mathrm{~g}$ samples of fresh placental tissue were homogenized in $80 \mathrm{ml}$ Buffer $1 \quad(250 \mathrm{mmol} / 1$ sucrose, $10 \mathrm{mmol} / 1$ Hepes, $\mathrm{pH} 7 \cdot 0$ containing $1 \mathrm{nmol} / 1$ protease inhibitor 4-(2-aminoethyl)-benzenesulphonyl fluoride) for $20 \mathrm{~s}$, using a metal-blade tissue homogenizer (Ultra-turrax, T25 and S25N 8 G dispersing tool; Jenke and Kunkle GMBH and Co., Staufen, Germany). The homogenate was centrifuged at $10000 \boldsymbol{g}$ for $10 \mathrm{~min}$ (Beckman JA14) and the supernatant collected. The pellet was re-extracted in Buffer 1 and recentrifuged at $10000 \mathrm{~g}$ for a further $10 \mathrm{~min}$. The pooled supernatants were then centrifuged at $40000 \mathrm{~g}$ for $60 \mathrm{~min}$. The resultant pellet was resuspended in $12 \mathrm{ml}$ Buffer 1 and homogenized with ten strokes of a Dounce glass homogenizer. MVMs were prepared by adding $4 \mathrm{~mol} / 1 \mathrm{MgCl}_{2}$ (final concentration of $12 \mathrm{mmol} / \mathrm{l}$ ) and rocked on ice for $20 \mathrm{~min}$. This solution was then centrifuged at $2500 \boldsymbol{g}$ for $15 \mathrm{~min}$ to sediment the $\mathrm{Mg}^{2+}$-aggregated MVM, which was resuspended in $2 \mathrm{ml}$ Buffer 2 (250 mmol/l sucrose, $10 \mathrm{mmol} / \mathrm{l}$ Hepes, $\mathrm{pH} 7 \cdot 0)$ in a Dounce homogenizer. MVMs were aliquoted, frozen in liquid $\mathrm{N}_{2}$ and stored at $-80{ }^{\circ} \mathrm{C}$. The supernatant was 
further centrifuged at $40000 \mathrm{~g}$ for $30 \mathrm{~min}$. The BM pellet was resuspended in $2 \mathrm{ml}$ Buffer 2 with a Dounce homogenizer and applied to a continuous 20\% Percoll sucrose gradient (preformed by centrifugation at $30000 \boldsymbol{g}$ for $30 \mathrm{~min})$. The gradient was centrifuged at $40000 \boldsymbol{g}$ for 45 min using a Beckman JA 20 fixed rotor (Beckman Instruments, Palo Alto, CA, USA). The fraction collected at the middle of the gradient was further purified by centrifugation at $67000 \boldsymbol{g}$ for $20 \mathrm{~min}$ (Beckman Optima TLX Ultracentrifuge, fixed Beckman TLA $100 \cdot 4$ rotor). Purified BMs were aliquoted, frozen in liquid $\mathrm{N}_{2}$ and stored at $-80^{\circ} \mathrm{C}$.

\section{Orientation assay}

Membrane vesicle orientation was assessed using a previously published method (Illsley et al. 1990) and involved measuring the binding of concanavalin A-fluorescein isothiocynate (Con A-FITC) to the membrane vesicle fractions. To determine specific membrane binding, $0.5 \mathrm{~mol} / 1$ methyl- $\alpha-\mathrm{D}-\mathrm{mannopyranoside} \mathrm{(which} \mathrm{specifi-}$ cally displaces bound concanavalin A to $\alpha$-mannosyl and $\alpha$-glucosyl residues on the external membrane surfaces) was added. Vesicle lysis was carried out by three freeze (liquid $\mathrm{N}_{2}$ ) and thaw (at $37^{\circ} \mathrm{C}$ ) cycles. The fraction of right-side-out vesicles was taken as the ratio of Con A-FITC binding in the presence and absence of methyl$\alpha$-D-mannopyranoside, measured before and after lysis. Con A-FITC was measured in a Perkin Elmer LS 50B Luminescence Spectrometer using a $515 \mathrm{~nm}$ emmission cut-on filter (slit width 20) and $490 \mathrm{~nm}$ excitation cut-on filter (slit width 15).

\section{Alkaline phosphatase assay}

The MVM marker, alkaline phosphatase, was assayed using a previously published method (Kelly \& Hamilton 1970, Lafond et al. 1988, Illsley et al. 1990). In brief, a $50 \mu \mathrm{l} \mathrm{sample}$ (diluted in $0.02 \mathrm{~mol} / 1 \mathrm{NaOH}$ ) was incubated with $200 \mu \mathrm{l}$ assay mixture $(2 \mathrm{mg} / \mathrm{ml} p$-nitrophenyl phosphate, $25 \mathrm{mmol} / 1$ sodium borate $(\mathrm{pH} 9 \cdot 8), 2 \mathrm{mmol} / 1$ $\mathrm{MgCl}_{2}$ ) for $30 \mathrm{~min}$ at $37^{\circ} \mathrm{C}$ and the reaction stopped with $600 \mu \mathrm{l} 0.25 \mathrm{~mol} / \mathrm{l} \mathrm{NaOH}$. The absorbance was measured at $405 \mathrm{~nm}$. Standards ranged from 0.25 to $0.004 \mu \mathrm{mol} / \mathrm{ml}$.

\section{Dihydroalprenolol binding assay}

BM purity was determined using a modified dihydroalprenolol binding method (Williams et al. 1976). Placental homogenate or enriched vesicles (10-50 $\mu \mathrm{g}$ protein) were incubated in the presence of $10 \mathrm{nmol} / 1\left[{ }^{3} \mathrm{H}\right]$ dihydroalprenolol $\left(\left[\mathrm{H}^{3}\right]\right.$ DHAP, Amersham, Amersham, Bucks, UK) in a total volume of $100 \mu$ incubation buffer (50 mmol/1 Tris-HCl, $10 \mathrm{mmol} / 1 \mathrm{MgCl}_{2}, \mathrm{pH} \mathrm{7.4)}$ for $15 \mathrm{~min}$ at $37^{\circ} \mathrm{C}$. DL-Propranolol $(10 \mu \mathrm{mol} / \mathrm{l})$ was used to determined non-specific binding. After incubation, prepar- ations were vacuum filtered on $0 \cdot 45-\mu \mathrm{m}$ filters through a Millipore 96-well Multiscreen plate (Bedford, MA, USA), which separated free radioactivity from bound. Filters retaining bound radiation were punched out, dried, placed in Optiphase 'HiSafe' 3 scintillant (Wallac Scintillation Products, Turku, Finland) and counted on a Liquid Scintillation Spectrometer (Model 1409, Wallac). Specific binding was determined by subtracting the non-specific binding from the total counts bound. $\left[{ }^{3} \mathrm{H}\right] \mathrm{DHAP}-$ specific binding to each of the fractions was represented as mmol $\left[{ }^{3} \mathrm{H}\right] \mathrm{DHAP}$ per $\mu \mathrm{g}$ membrane protein.

\section{Effect of PTH(1-34) and PTHrP peptides on calcium efflux}

The uptake of calcium by placental vesicles was measured by modification to a standard filtration method (Donowitz et al. 1987). Membrane vesicles (50-100 $\mu \mathrm{g}$ protein for BM and 15-20 $\mu \mathrm{g}$ protein for MVM vesicles) were preloaded with incubation buffer $(250 \mathrm{mmol} / 1$ sucrose, $30 \mathrm{mmol} / 1$ Tris, $10 \mathrm{mmol} / 1$ Hepes, $5 \mathrm{mmol} / 1 \mathrm{MgCl}_{2}$, $\mathrm{pH}$ 7.4), $\mathrm{CaCl}_{2}$ (as required), and $5 \mu \mathrm{Ci}$ calcium-45 (DuPont NEN, Boston, MA, USA) in a total volume of $100 \mu \mathrm{l}$. The preload was carried out by freezing the above mixture and vesicles in liquid $\mathrm{N}_{2}$ and thawing in an ice bath. Preloaded vesicles were filtered under vacuum on $0.45 \mu \mathrm{m}$ Duropore membrane filters (Millipore Corporation) and washed three times with filtration buffer $(250 \mathrm{mmol} / 1$ sucrose,

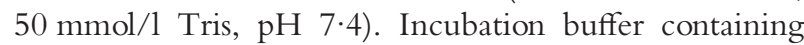
peptide was then added to BM and MVM vesicles (with or without PTH(1-34), PTHrP(1-34) and PTHrP(67-94) at concentrations up to $50 \mathrm{nmol} / \mathrm{l}$ ) and shaken continually at $37^{\circ} \mathrm{C}$ for $30 \mathrm{~min}$. In separate experiments in $\mathrm{BM}$ vesicles only, PTH(1-34), PTHrP(1-34) and PTHrP(67-94) $(50 \mathrm{nmol} / \mathrm{l})$ were incubated (at $37^{\circ} \mathrm{C}$ for $30 \mathrm{~min}$ ) in the presence and in the absence of the $\mathrm{PTH} / \mathrm{PTHrP}$ receptor antagonist, $\mathrm{PTHrP}(7-34)(50 \mathrm{nmol} / \mathrm{l})$. The plate was again filtered under suction and rinsed three times. The plate was dried in a $37^{\circ} \mathrm{C}$ incubator cabinet before filters were punched out into scintillation vials containing Optiphase 'HiSafe' 3 scintillant using a Multiscreen Punch Assembly (Millipore Corporation) and counted on a Liquid Scintillation Spectrometer (Model 1409, Wallac).

\section{Protein assay}

The protein content of each of the membranes was determined by the protein dye-binding method described by Bradford (1976) using bovine serum albumin as a reference standard.

\section{Statistical analyses}

Statistical computations were performed using a commercially available statistical analysis package (Statgraphics, STSC, Rockville, MD, USA). The homogeneity of data was tested using Bartlett's test $(P<0 \cdot 05)$. Subsequently, two sample comparisons were analysed using Student's 
Table 1 Representation of various membrane vesicle parameters: orientation, alkaline phosphatase activity (MVM marker) and dihydroalprenolol binding (BM marker). Orientation was calculated as \% right side out (percent correct orientation). Alkaline phosphatase and dihydroalprenolol were determined as fold enrichment with respect to the initial homogenate. All data are expressed as means \pm S.E.M. $(n=8)$

\begin{tabular}{|c|c|}
\hline \multicolumn{2}{|c|}{ Membrane vesicles } \\
\hline Microvillous & Basal \\
\hline $99 \cdot 0 \pm 0 \cdot 3$ & $102 \cdot 4 \pm 1 \cdot 7$ \\
\hline $12 \cdot 2 \pm 2 \cdot 8$ & $4 \cdot 3 \pm 0 \cdot 9$ \\
\hline $1 \cdot 7 \pm 0 \cdot 7$ & $12 \cdot 9 \pm 6 \cdot 0$ \\
\hline
\end{tabular}

$t$-test, and three or more data sets were analysed using analysis of variance (ANOVA) with post-hoc analysis using a Newman-Keuls test. Statistical significance was indicated by $P<0 \cdot 05$. Data are expressed as means \pm standard error of the mean (s.E.M.). Because of the variable responses in calcium efflux between placentae, the calcium data were calculated as 'percent of control'.

\section{Results}

Orientation and membrane markers

Orientation and membrane markers were used to assess the configuration and fractionation of the respective membrane preparations. Both MVM (99.0 $\pm 0 \cdot 3 \%)$ and BM $(102 \cdot 4 \pm 1 \cdot 7 \%)$ were approximately $100 \%$ in the correct or right-side-out orientation (Table 1). Alkaline phosphatase activity (an MVM marker) showed a three-fold increase in MVM relative to BM (Table 1). Table 1 also shows that dihydroalprenolol (a BM marker) binding was six-fold greater in the BM preparations with respect to that seen in the MVM fractions.

Effect of exogenous calcium and magnesium on the preload procedure

Dose-response curves were used to investigate whether calcium or magnesium had any effect on the uptake of calcium during the preload procedure. Calcium or magnesium were preloaded at various concentrations and incubated for $15 \mathrm{~min}$ at $37^{\circ} \mathrm{C}$. There was no significant difference between the two membrane vesicle preparations, with an approximate 1.5 -fold increase in radioactive calcium uptake with either calcium or magnesium. On the basis of our data, $0.4 \mathrm{mmol} / \mathrm{l}$ calcium and $10 \mathrm{mmol} / 1$ magnesium were used in all subsequent experiments.

Effect of PTH(1-34) and PTHrP peptides on calcium efflux $\mathrm{PTH}(1-34), \mathrm{PTHrP}(1-34)$ and $\mathrm{PTHrP}(67-94)$ at various concentrations were added to the solution surrounding the
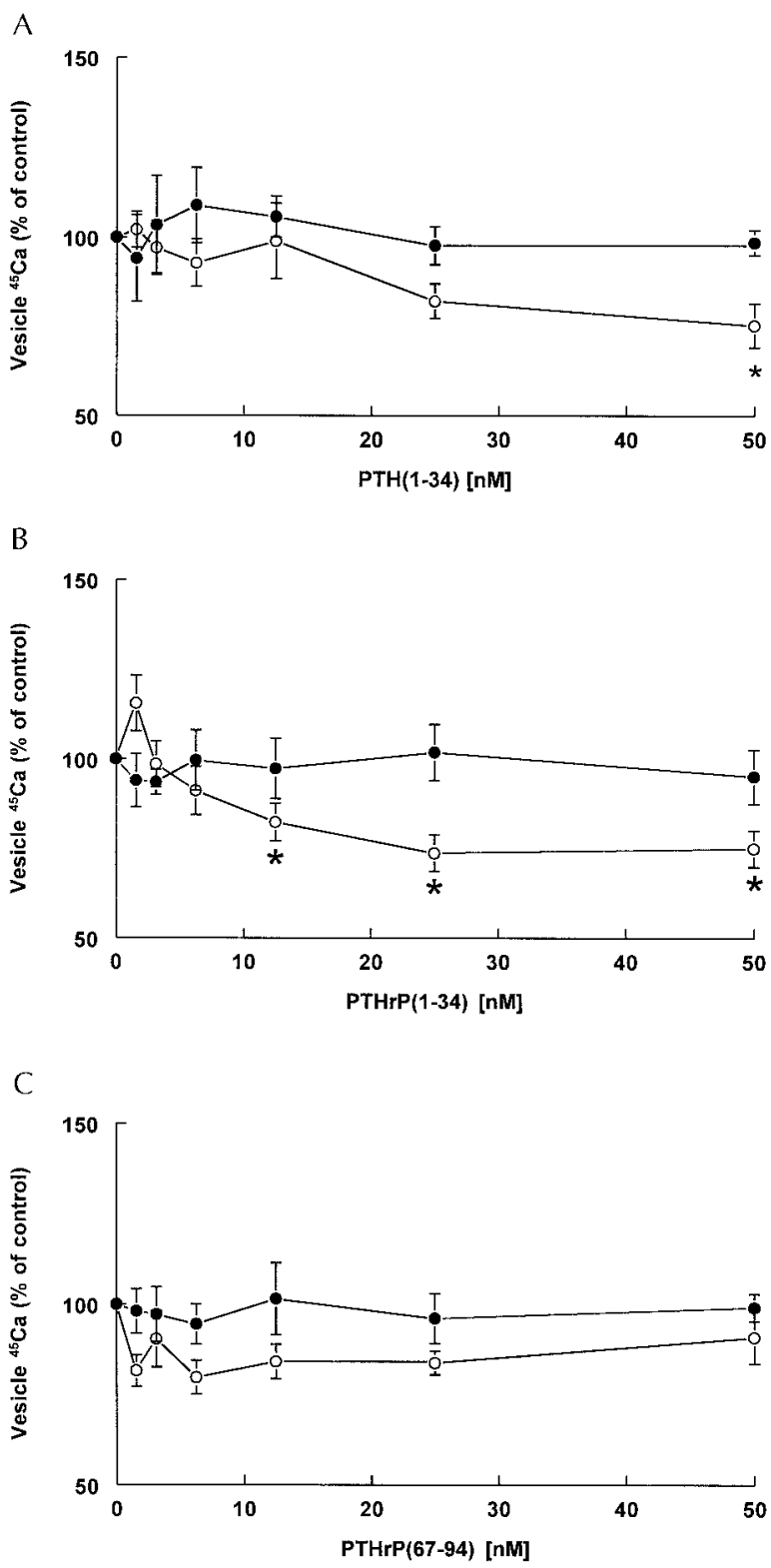

Figure 1 Effects of $\mathrm{PTH}(1-34)(\mathrm{A}), \operatorname{PTHrP}(1-34)$ (B) and PTHrP(67-94) (C) on vesicle calcium-45 $\left({ }^{45} \mathrm{Ca}\right)$ in $\mathrm{BM}(\bigcirc)$ and in MVM (-) vesicles. Vesicle calcium-45 is calculated as \% of time zero control. Membrane vesicles were preloaded (with $0.4 \mathrm{mmol} / \mathrm{l}$ $\mathrm{Ca}^{2+}$ and $10 \mathrm{mmol} / \mathrm{I} \mathrm{Mg}^{2+}$ ) and then incubated in the presence of varying concentrations of $\mathrm{PTH}(1-34)$ and PTHrP peptides for $15 \mathrm{~min}$ at $37^{\circ} \mathrm{C}$. At $50 \mathrm{nmol} / \mathrm{I} \mathrm{PTH}(1-34)$ and from $12.5 \mathrm{nmol} / \mathrm{l}$ PTHrP(1-34) there was a significant efflux, as indicated by a decrease from basal in vesicle calcium- 45 in $B M\left({ }^{*} P<0 \cdot 05\right.$ from zero dose, ANOVA). Data are expressed as means \pm S.E.M. $(n=8)$.

preloaded vesicles and incubated for $15 \mathrm{~min}$ at $37^{\circ} \mathrm{C}$. None of the peptides examined had a significant effect on calcium efflux in the MVM fractions (Fig. 1). PTHrP(6794) showed no significant increase in calcium efflux in 
Table 2 Effect of PTHrP/PTH receptor antagonist PTHrP(7-34) on vesicle calcium-45 $\left({ }^{45} \mathrm{Ca}\right)(\mathrm{pmol} / \mathrm{h}$ per $\mathrm{mg}$ protein) in $\mathrm{BM}$ vesicles in the presence of $50 \mathrm{nmol} / \mathrm{IPTH}(1-34), \operatorname{PTHrP}(1-34)$ and midmolecule PTHrP(67-94). BM vesicles were preloaded (with $0.4 \mathrm{mmol} / \mathrm{l} \mathrm{Ca}^{2+}$ and $10 \mathrm{mmol} / \mathrm{I} \mathrm{Mg}^{2+}$ ) and then incubated in the presence of PTH(1-34) or the PTHrP peptides, with and without $\operatorname{PTHrP}(7-34)(50 \mathrm{nmol} / \mathrm{l})$, for $15 \mathrm{~min}$ at $37^{\circ} \mathrm{C}$. Student's paired $t$-tests were performed between control and presence of $\operatorname{PTHrP}(7-34)$ for the various peptide combinations. In the presence of the PTHrP/PTH receptor antagonist PTHrP(7-34), there was a reduction in efflux (indicated by a decrease in vesicle calcium-45) in response to $\mathrm{PTH}(1-34)$ and $\mathrm{PTHrP}(1-34)$. Data are expressed as means \pm S.E.M. $(n=8)$

\section{Vesicle ${ }^{45} \mathrm{Ca}$}

( $\mathrm{pmol} / \mathrm{h}$ per mg protein)

\begin{tabular}{llll} 
Peptide & Control & & PTHrP(7-34) \\
\cline { 2 - 2 } No peptide & $225 \pm 25$ & & $274 \pm 45$ \\
PTH(1-34) & $199 \pm 23$ & & $242 \pm 29^{*}$ \\
PTHrP(1-34) & $169 \pm 14$ & & $230 \pm 15^{* *}$ \\
PTHrP(67-94) & $237 \pm 22$ & & $275 \pm 36$
\end{tabular}

Significant reductions in efflux compared with control: ${ }^{*} P 0 \cdot 01,{ }^{* *} P 0.006$.

BM. At $50 \mathrm{nmol} / 1 \mathrm{PTH}(1-34)$ and from $12.5 \mathrm{nmol} / \mathrm{l}$ PTHrP(1-34) there was a significant efflux of calcium from BM compared with basal efflux without peptide $(P<0 \cdot 05, n=8$, ANOVA; Fig. 1$)$.

\section{Effect of PTH/PTHrP receptor antagonist on calcium efflux}

The common PTH/PTHrP receptor antagonist, PTHrP(7-34), was also added to the solution surrounding the preloaded vesicles, to investigate its effects on efflux of calcium-45 (pmol/h per $\mathrm{mg}$ protein) from $\mathrm{BMs}$ in the presence of $\mathrm{PTH}(1-34)$, PTHrP(1-34) and PTHrP(6794) (Table 2). At $50 \mathrm{nmol} / \mathrm{l}, \mathrm{PTH}(1-34)$ and $\mathrm{PTHrP}(1-$ 34) caused significant efflux of calcium from the $\mathrm{BM}$ $(P<0.01$ and $P<0.006$ respectively, $n=8$, Student's $t$-test; Table 2). Addition of the PTH/PTHrP receptor antagonist, $\mathrm{PTHrP}(7-34)$, significantly reduced the calcium efflux observed in the $\mathrm{BM}$ vesicles in the presence of $\mathrm{PTH}(1-$ 34) $(P<0 \cdot 01)$ and PTHrP $(1-34) \quad(P<0 \cdot 006)$. The midmolecule, PTHrP(67-94), in the absence or presence of the receptor antagonist had no effect on calcium efflux from BMs.

\section{Discussion}

The syncytiotrophoblast represents the primary interface between the maternal and fetal circulations in the placenta. The use of simultaneous preparations of MVMs (maternal facing) and BMs (fetal facing) from term human placental syncytiotrophoblast provides a useful tool with which to explore the regulation of calcium efflux across the placenta (Smith et al. 1974). Before the recognition of midmolecule
PTHrP peptides as regulators of placental calcium transport, it was reported that PTH influenced phosphate transport across purified placental MVMs and increased cAMP accumulation (Brunette et al. 1989). Receptors for PTH were implicated in both MVM and BM, but adenylate cyclase activity was found exclusively in the placental BMs (Smith et al. 1974, Lafond et al. 1988). More recent investigation of G-proteins in these membrane vesicles indicates that the syncytiotrophoblast BM vesicle preparation contains all the elements necessary to allow activation of the PTH/PTHrP receptor (el Mabrouk et al. 1996). Calcium transport across the MVM of the human placental syncytiotrophoblast is assisted by a specific membrane carrier and the movement of calcium through the syncytiotrophoblast is aided by calciumbinding proteins. In the MVM, calcium uptake is reported to be time dependent and it was found that calcium entered the cell via two distinct transporters and was bound to internal sites (Kamath et al. 1992). High-affinity calcium pumps in human and rat placentae were found to reside in the BM portion of the syncytiotrophoblast and it was concluded that these pumps played a part in the transport of calcium from the maternal to the fetal circulation (Borke et al. 1989). Although little information is available on the efflux of calcium from the syncytiotrophoblast, the presence of a pump with characteristics similar to those of a $\mathrm{Ca}^{2+}-\mathrm{Mg}^{2+}$-ATPase pump has been suggested to be present, with greater activity in the BM compared with the MVM, suggesting the possibility of a role in calcium transport (Fisher et al. 1987, Borke et al. 1989, Lafond et al. 1991). Thus the simultaneous membrane vesicle preparation is a useful model system for the study of the role of PTHrPs in the movement of calcium across the placental syncytiotrophoblast.

In this study, the vesicles produced were in the correct or right-side-out orientation and the specific membrane markers demonstrated that MVMs were successfully isolated from $\mathrm{BMs}$, indicating that this system was optimized to investigate calcium transport across the respective syncytiotrophoblast membranes. With these simultaneously prepared MVMs and BMs, we have unequivocally demonstrated that both $\mathrm{PTH}(1-34)$ and PTHrP(1-34) regulate calcium transport across the BM, but not the MVM, of the syncytiotrophoblast. Although the relative potencies remain to be established, $\mathrm{PTHrP}(1-$ 34) in BM vesicles was found to stimulate significant calcium efflux at a dose of $12.5 \mathrm{nmol} / 1$, whereas PTH(134)-stimulated efflux was significant at $50 \mathrm{nmol} / \mathrm{l}$. The PTHrP midmolecule had no significant effect on calcium efflux at either membrane. Furthermore, we were able to demonstrate that the $\mathrm{PTH} / \mathrm{PTHrP}$ receptor antagonist, PTHrP(7-34), antagonized the calcium efflux from BMs in response to both $\mathrm{PTH}(1-34)$ and $\mathrm{PTHrP}(1-34)$, indicating a receptor-mediated event. The data presented in this paper indicate that $\mathrm{PTH}(1-34)$ and $\mathrm{PTHrP}(1-34)$, acting through the $\mathrm{PTH} / \mathrm{PTHrP}$ receptor, can stimulate 
calcium transport across the BM, but not the MVM, of the human syncytiotrophoblast. In this way, $\mathrm{PTH}(1-34)$ and PTHrP(1-34) may contribute to the overall maintenance of calcium transfer across the placenta, which has previously been reported in the literature to be controlled, in the main, by midmolecule PTHrP peptides (Rodda et al. 1988, Care et al. 1990).

In contrast to the sheep studies carried out earlier in gestation (Rodda et al. 1988), the midmolecule, PTHrP(67-94), had no effect on calcium transport across human MVMs and BMs. Previous studies of the effects of PTH or N-terminal PTHrP on placental calcium transport have been controversial, and confounded by the use of inappropriate models. For example, the presence of intact fetal parathyroids, kidneys and skeleton, in addition to the use of a rat decapitation model, complicate the interpretation of the data (Robinson et al. 1989, Barlet et al. 1990, Shaw et al. 1991). The presence of responsive PTH/ PTHrP receptors in the human placenta, and specifically on the BMs of the syncytiotrophoblast (Smith et al. 1974, Lafond et al. 1988, el Mabrouk et al. 1996), together with the present observations, are indicative of a potential role of N-terminal PTH and PTHrP in stimulating human placental calcium transport. However, the effects observed in this in vitro human model were modest, and may represent a modulating effect either of local PTHrP or of circulating PTH. Although knockout studies indicated that the $\mathrm{PTH} / \mathrm{PTHrP}$ receptor was not necessary for placental calcium transport (Kovacs et al. 1996), $\mathrm{N}$-terminal PTH or PTHrP activity may contribute to alternate calcium transport mechanisms apparent in the animals null for PTHrP or calcium sensor receptor in which placental calcium transport is not completely ablated (Kovacs et al. 1996, 1998).

The physiological contribution of the effect of $\mathrm{N}$-terminal PTH or PTHrP on human placental membrane vesicles remains to be fully elucidated and possible differences in the control of placental calcium transport arising from gestational age and species differences cannot be disregarded. Further functional studies in animals null for PTHrP, PTH and PTH/PTHrP and calcium sensor receptors should contribute significantly towards understanding the relative contributions of all these mechanisms to placental calcium transport during fetal development. These approaches would be complemented by studies characterizing the second-messenger pathways involved and the development of an in vitro placental tissue explant system in which the specific mechanisms of PTHrP action in the placenta could be explored.

\section{Acknowledgements}

This work was supported by a Project Grant from the National Health and Medical Research Council of Australia (M E W, GE R), Program Grant (J M M) and
Principal Research Fellowship (GE R). The authors grateful acknowledge the assistance of clinical Research Nurses Nicola Davies, Jenny Robinson and Jane Atkinson, and the Obstetric and Midwifery staff of the Royal Women's Hospital for their cooperation. The authors would like to thank Kerryn Westcott for her assistance.

\section{References}

Alsat E, Haziza J, Scippo M-L, Frankenne F \& Evain-Brion D 1993 Increase in epidermal growth factor receptor and its mRNA levels by parathyroid hormone (1-34) and parathyroid hormone-related protein (1-34) during differentiation of human trophoblast cells in culture. Journal of Cellular Biochemistry 53 32-42.

Barlet JP, Davicco MJ \& Coxam V 1990 Synthetic parathyroid hormone-related peptide (1-34) fragment stimulates placental calcium transfer in ewes. Journal of Endocrinology 127 33-37.

Borke JL, Caride A, Verma AK, Kelley LK, Smith CH, Penniston JT \& Kumar R 1989 Calcium pump epitopes in placental trophoblast basal plasma membranes. American Journal of Physiology 257 C341-C346.

Bowden SJ, Emly JF, Hughes SV, Powell G, Ahmed A, Whittle MJ, Ratcliffe JG \& Ratcliffe WA 1994 Parathyroid hormone-related protein in human term placenta and membranes. Journal of Endocrinology 142 217-224.

Bradford MM 1976 A rapid and sensitive method for the quantification of microgram quantities of protein utilizing the principle of protein-dye binding. Analytical Biochemistry 72 248-254.

Brunette MG, Auger D \& Lafond J 1989 Effect of parathyroid hormone on $\mathrm{PO}_{4}$ transport through the human placenta microvilli. Pediatric Research 25 15-18.

Care AD, Abbas SK, Pickard DW, Barri M, Drinkhill M, Findlay JBC, White IR \& Caple IW 1990 Stimulation of ovine placental transport of calcium and magnesium by mid-molecule fragments of human parathyroid hormone-related protein. Experimental Physiology 75 605-608.

Curtis NE, Ho PWM, King RG, Farrugia W, Moses EK, Gillespie MT, Moseley JM, Rice GE \& Wlodek ME 1997 The expression of parathyroid hormone related protein $\mathrm{mRNA}$ and immunoreactive protein in human amnion and choriodecidua is increased at term compared with preterm gestation. Journal of Endocrinology 154 103-112.

Curtis NE, Thomas RJ, Gillespie MT, King RG, Rice GE \& Wlodek ME 1998 Parathyroid hormone-related protein (PTHrP) mRNA splicing and parathyroid hormone/PTHrP receptor mRNA expression in human placenta and fetal membranes. Journal of Molecular Endocrinology 21 225-234.

Dalle M, Dauprat-Dalle P \& Barlet J-P 1992 Parathyroid hormonerelated peptide inhibits oxytocin-induced rat uterine contractions in vitro. Archives Internationales de Physiologie, de Biochimie et de Biophysique 101 251-254.

Deftos LJ, Burton DW, Brandt DW, Pinar H \& Rubin LP 1994 Neoplastic hormone-producing cells of the placenta produce and secrete parathyroid hormone-related protein. Studies by immunohistology, immunoassay, and polymerase chain reaction. Laboratory Investigation 71 847-852.

Donowitz M, Emmer E, McCullen J, Reinlib L, Cohen ME, Rood RP, Madara J, Sharp GWG, Murer H \& Malmstrom K 1987 Freeze-thaw and high-voltage discharge allow macromolecule uptake into ileal brush-border vesicles. American Journal of Physiology 252 G723-G735.

Dunne FP, Ratcliffe WA, Mansour P \& Heath DA 1994 Parathyroid hormone related protein (PTHrP) gene expression in fetal and extra-embryonic tissues of early pregnancy. Human Reproduction 9 149-156. 
Ferguson JE, Gorman JV, Bruns DE, Weir EC, Burtis WJ, Martin TJ \& Bruns ME 1992 Abundant expression of parathyroid hormonerelated protein in human amnion and its association with labor. PNAS 89 8384-8388.

Fisher GJ, Kelley LK \& Smith CH 1987 ATP-dependent calcium transport across basal plasma membranes of human placental trophoblast. American Journal of Physiology 252 C38-C46.

Germain AM, Attaroglu H, MacDonald PC \& Casey ML 1992 Parathyroid hormone-related protein mRNA in avascular human amnion. Journal of Clinical Endocrinology and Metabolism $\mathbf{7 5}$ 1173-1175.

Illsley NP, Wang Z, Gray A, Sellers MC \& Jacobs MM 1990 Simultaneous preparation of paired, syncytial microvillous and basal membranes from human placenta. Biochimica et Biophysica Acta 1029 218-226.

Kamath SG, Kelley LK, Friedman AF \& Smith CH 1992 Transport and binding in calcium uptake by microvillous membrane of human placenta. American Journal of Physiology 262 C789-C794.

Kelley LK, Smith CH \& King BF 1983 Isolation and partial characterization of the basal cell membrane of human placental trophoblast. Biochimica et Biophysica Acta 734 91-98.

Kelly MH \& Hamilton JR 1970 A microtechnique for the assay of intestinal alkaline phosphatase. Results in normal children and in children with celiac disease. Clinical Endocrinology 3 33-43.

Kovacs CS, Lanske B, Hunzelman JL, Guo J, Karaplis AC \& Kronenberg HM 1996 Parathyroid hormone-related peptide (PTHrP) regulates fetal-placental calcium transport through a receptor distinct from the $\mathrm{PTH} / \mathrm{PTHrP}$ receptor. PNAS $\mathbf{9 3}$ $15233-15238$.

Kovacs CS, Ho-Pao CL, Hunzelman JL, Lanske B, Fox J, Seidman CE \& Kronenberg HM 1998 Regulation of murine fetal-placental calcium metabolism by the calcium-sensing receptor. Journal of Clinical Investigation 101 2812-2820.

Lafond J, Auger D, Fortier J \& Brunette MG 1988 Parathyroid hormone receptor in human placental syncytiotrophoblast brush border and basal plasma membranes. Endocrinology 123 2834-2840.

Lafond J, Leclerc M \& Brunette MG 1991 Characterization of calcium transport by basal plasma membranes from human placental syncytiotrophoblast. Journal of Cellular Physiology 148 17-23.

Lee K, Deeds JD \& Segre GV 1995 Expression of parathyroid hormone-related peptide and its receptor messenger ribonucleic acids during fetal development of rats. Endocrinology 136 453-463.

el Mabrouk M, Simoneau L, Bouvier C \& Lafond J 1996 Asymmetrical distribution of $\mathrm{G}$ proteins in syncytiotrophoblastic brush-border and basal-plasma membranes of human term placenta. Placenta 17 471-477.

Macgill K, Wlodek M, Moseley JM, Martin TJ, Brennecke SP \& Rice GE 1997 Vascular effects of PTHrP(1-34) in the human fetal-placental circulation. Placenta 18 587-592.

MacIsaac RJ, Heath JA, Rodda CP, Moseley JM, Care AD, Martin TJ \& Caple IW 1991 Role of the fetal parathyroid glands and PTHrP in the regulation of placental transport of calcium, magnesium and inorganic phosphate. Reproduction, Fertility and Development 3 447-457.

Mandsager NT, Brewer AS \& Myatt L 1994 Vasodilator effects of parathyroid hormone, parathyroid hormone-related protein, and calcitonin gene-related peptide in the human fetal-placental circulation. Journal of the Society for Gynecologic Investigation $\mathbf{1}$ $19-24$.
Moniz C, Burton PBJ, Malik AN, Dixit M, Banga JP, Nicolaides K, Quirke P, Knight DE \& McGregor AM 1990 Parathyroid hormone-related peptide in normal human fetal development. Journal of Molecular Endocrinology 5 259-266.

Moseley JM, Hayman JA, Danks JA, Alcorn D, Grill V, Southby J \& Horton MA 1991 Immunohistochemical detection of parathyroid hormone-related protein in human fetal epithelia. Journal of Clinical Endocrinology and Metabolism 73 478-484.

Paspaliaris V, Vargas SJ, Gillespie MT, Williams ED, Danks JA, Moseley JM, Story ME, Pennefather JN, Leaver DD \& Martin TJ 1992 Oestrogen enhancement of the myometrial response to exogenous parathyroid hormone-related protein (PTHrP), and tissue localization of endogenous PTHrP and its mRNA in the virgin rat uterus. Journal of Endocrinology 134 415-425.

Philbrick WM, Wysolmerski JJ, Galbraith S, Holt E, Orloff JJ, Yang KH, Vasavada RC, Weir EC, Broadus AE \& Stewart AF 1996 Defining the roles of the parathyroid hormone-related protein in normal physiology. Physiological Reviews 76 127-173.

Robinson NR, Sibley CP, Mughal MZ \& Boyd RD 1989 Fetal control of calcium transport across the rat placenta. Pediatric Research 26 109-115.

Rodda CP, Kubota M, Heath JA, Ebeling PR, Moseley JM, Care AD, Caple IW \& Martin TJ 1988 Evidence for a novel parathyroid hormone-related protein in fetal lamb parathyroid glands and sheep placenta: comparisons with a similar protein implicated in humoral hypercalcaemia of malignancy. Journal of Endocrinology 117 261-271.

Shaw AJ, Mughal MZ, Maresh MJ \& Sibley CP 1991 Effects of two synthetic parathyroid hormone-related protein fragments on maternofetal transfer of calcium and magnesium and release of cyclic AMP by the in situ perfused rat placenta. Journal of Endocrinology 129 399-404.

Sideri M, de Vergilsis G, Rainoldi R \& Remotti G 1983 The ultrastructural basis of nutritional transfer: evidence of different patterns in the plasma membranes of the multilayered placental barrier. Throphoblast Research 1 15-26.

Smith NC, Brush MG \& Luckett S 1974 Preparation of human placental villous surface membrane. Nature 252 302-303.

Thiede MA, Daifotis AG, Weir EC, Brines ML, Burtis WJ, Ikeda K, Dreyer BE, Garfield RE \& Broadus AE 1990 Intrauterine occupancy controls expression of the parathyroid hormone-related peptide gene in preterm rat myometrium. PNAS 87 6969-6973.

Tucci J, Hammond V, Senior PV, Gibson A \& Beck F 1996 The role of foetal parathyroid hormone-related protein in transplacental calcium transport. Journal of Endocrinology 17 159-164.

Williams LT, Jarett L \& Lefkowitz RJ 1976 Adipocyte b-adrenergic receptors. Journal of Biological Chemistry 251 3096-3104.

Williams ED, Leaver DD, Danks JA, Moseley JM \& Martin TJ 1994 Effect of parathyroid hormone-related protein (PTHrP) on the contractility of the myometrium and the localization of PTHrP in the uterus of pregnant rats. Journal of Reproduction and Fertility 102 209-214.

Wysolmerski JJ \& Stewart AF 1998 The physiology of parathyroid hormone-related protein: an emerging role as a developmental factor. Annual Review of Physiology 60 431-460.

Received 14 January 2000

Accepted 2 May 2000 